\title{
Contribution of Mustafa Lutfi al-Manfaluti to Arabic Short Story: A Brief Study
}

\author{
Joynal Abedin \\ Research Scholar, Department of Arabic, Assam University, Silchar, Assam-788011.
}

\begin{abstract}
This paper analyzes the contribution of Mustafa Lutfi al-Manfaluti to Arabic short story. AlManfaluti was a distinguished Arabic litterateur of the early $20^{\text {th }}$ century. He had a far greater influence of his day than writers on the subject have given him credit for. An attempt has been made in this paper to deal with his work "Al-Abarat".
\end{abstract}

Keywords: Al-Abarat, contribution to Arabic short story, Mustafa Lutfi al-Manfaluti, original and translated works, Theme and style.

\section{Introduction:}

Mustafa Lutfi al-Manfaluti was born in 1876 in Manfalut, a town in the province of Asyut in Upper Egypt. He was brought up in a noble family. His father was a judge in a Muslim court. His father was from an Arab descend and his mother was from Turkish descend. The family considered it distinguished and even claimed that its family tree went back to the Prophet Muhammad (P.B.U.H.). ${ }^{[1]}$

He got his early education in Manfalut in a traditional manner from a primary school attached to a mosque. He received a farm religious education and like other children learned parts of the holly Quran by heart when he was nearly eleven years old. His father sent him to al-Azhar University in 1888 to follow in the footsteps of his father. Al-Manfaluti received a traditional education at the al-Azhar University in Cairo. $\mathrm{He}$ spent ten years at this university where he received scientific knowledge, literary knowledge and religious knowledge. In those days which was not long usually for a course of study. It was comprised more or less, the equivalent of a secondary as well as post secondary education.

In spite of his inclination towards religious traditions, he diverted his whole attention towards learning language and literature. So he used to memorize poems and rare sayings and began to compose poems and write articles. As his reputation as a good writer got publicity in the university of al-Azhar, Muhammad Abduh took him to his company and apprised him of the best ways and means of developing literary talents and guided him living an ambitious life. During the period of his al-Azhar University, he studied about the Tafsir of the holly Quran, al-Balagha Min Amthal, Dalail al-I'jaj, Asrar al-Balagha etc. ${ }^{[2]}$

Mustafa Lutfi al-Manfaluti was genius in the construction and literature took over style pure in his articles and books. He began to compose poems and write articles. Here he seems to have been in touch with Muhammad Abduh whom he greatly admired. An admirer of the religious reformer Muhammad Abduh, his first publications were in the form of poetry. He was tried in 1897, together with Muhammad al-Bakri, for publishing a poem that was considered an insult to the Khedive Abbas, the second and of publishing of some weekly papers were brought against al-Manfaluti. As a result he was convicted and briefly imprisoned for six months. AlManfaluti had to serve his term of imprisonment, but al-Bakri was not sentenced because of his high officials. ${ }^{[3]}$

If al-Manfaluti did indeed study for ten years at the al-Azhar University, he must have gone down shortly after his release or perhaps even immediately after receiving his sentence. His fame began to prevail since 1907. He started contributing articles to the newspaper al-Mu'ayyad in support of the weekly under the title of al-Nazarat (The Looks). Al-Mu'ayyad, the mouthpiece of the militant Shaykh Ali Yusuf, strangely enough the newspaper, that was considered to be the voice of the party of the Khedive himself. Apparently, alManfaluti's faux pas was not held against him. ${ }^{[4]}$

During his period of imprisonment, Muhammad Abduh died and al-Manfaluti got much shock and became utterly disappointed and returned home. It was after pretty long time, he got all his ideas and ambitions revitalized and he contacted 'al-Mu'ayyad' to make it the pivot to his future success. When Sayyad Pasha became the minister of education he appointed al-Manfaluti the reporter of his Ministry. When the ministry of Sayyad Pasha fell and the opposition party formed the government, al-Manfaluti gave up his service. But afterwards when Sayyad Pasha again came into power with a staple position in the parliament, al-Manfaluti got reappointed in the ministry almost in an allied job of a reporter as he served before, and continued the office till his death. ${ }^{[5]}$

Al-Manfaluti was a litterateur by nature and was unique in his field of literature. He was the first story writer of the modern time. He could perfectly depict the story against its appropriate background which is 
otherwise impossible for a writer to do keeping away from such environments. He could prepare the ground for his story and narrate at ease not vividly. The secret of al-Manfaluti's writings getting wide acceptance, lay in the absence of pure and fair literature at that time. It was a period when the old literature appeared frozen on and the prospect for new literatures, were dominant. ${ }^{[6]}$

When al-Manfaluti started writing the social vices and virtues, joys and sorrows, information of attractive stories with pure and simple dictions in a free style and method put in an almost interesting order of incidents his pen-pictures of society was but correct reproduction of social life of the people and hence he got wide popularity with tears.

\section{His Literary Work:}

Al-Manfaluti's literary works may be discussed as: one of the collections of his works is 'al-Nazarat', which first came out under the title of 'al-Usbu'iyat' which is written in three volumes, first published in 1910,became immediately popular. One volume contains all his articles published in 'al-Mu'ayyad' such as some criticism, some collection of all writings and some stories. In 1915 al-Manfaluti published his next collection 'al-Abarat' (The Tears) which contains the stories, produced by the author as well as some other selected stories. There is another collection 'Mukhtarat al-Manfaluti' which contains some selected of poems and writings of old poets and writers.

He was the most translator-adapter of his period. Apart from 'arabizing' without any knowledge of a European language, four French romantic novels he delighted the public of the day with short prose pieces which were always emotional, high minded and elegantly worded. His translations of Alphonse Karr's sentimental novel 'Sous les Tilleuls' entitled as 'Magdulin' in1912. He adapted Francois Coppee's play 'Pour la Couronne' as a novel entitled as 'Fi Sabil al-Taj' in 1920, Edmond Rostand's 'Cyrano de Bargerac' adapted as a novel entitled as 'al-Shair' in 1921 and Barnardin de Saint Pierre's 'Paul et Virginie' entitled as 'al-Fadilah' in 1923.

Mustafa Lutfi Al-Manfaluti was one of the early essayists of the modern period. His essays are collected in three volumes of Al-Nazarat (The Views) which appeared first in Al-Muayyad. He was inspired by the reforming ideas of Muhammad Abduh. Al-Manfaluti wrote on the need for social uplift, on the rich and the poor, on charity and righteousness and the evils of drinking.

The style developed by him, Tariqat al-Manfaluti is somewhat highbrow. Al-Manfaluti chose his words with care. He retained a little saj' (Rhymed Prose) to give his prose a musical appeal. The stamp of his personal style is revealed in all his writings. ${ }^{[7]}$

\section{Theme And Style Of His Short Stories:}

The discussion of theme and style of short story is not necessarily a simple task for it is usually difficult to define the term itself. Although theme is considered as the "generalized abstract paraphrase of the inferred central or dominant idea of the story", it is not the moral or the meaning of the story- though it is very close to meaning. Therefore, in this research the term 'theme' will be used to indicate the subject and central idea of a story.

Al-Manfaluti's themes have always had quite an impact on his readers and brought him recognition. It was the theme of 'Al-Abarat' (published in 1915) that proclaimed him as a serious and capable writer. His stories simply reinforced that claim, when reading al-Manfaluti's stories it is inevitable to sense the sociality if we may- of the characters, actions and events. The reader is quickly immersed in the world, misery and reality of the characters. The reader cannot help, but share the agony and hardship which al-Manfaluti's characters endure. In short the theme of al-Manfaluti's stories is the reality of his readers.

Al-Manfaluti's critics have been at odds as to how they should categorize him as a writer. Some positively classify him merely as a translator; others make him merely a hack adapter of western fiction. Still others regard him as a sensitive translator with a special gift translating a work so that the new version becomes his very own creation. Some consider him primarily an essayist and story writer.

Al-Manfaluti cannot properly be called a genuine translator, for him himself knew no European languages. He simply reworked the literal and probably unpolished translations made for him by friends and put them into his own melancholy, sentimental style.

The subject matter of his stories themselves is extremely varied, as befits an author who needs to retain the attention and loyalty of his readers through a regular column extending over several years. Social, political and religious themes of various shorts form the author's staple diet, but there are also stories on purely literary themes, on the Arabic language itself and several inspired by events or situations in the writer's own life. A few stories are based on translated materiel. ${ }^{[8]}$ 


\section{Al-Manfaluti's Contribution To Arabic Short Story:}

His collection of short stories entitled 'al-Abarat' contains eight short stories of which four 'al-Yatim' (The Orphan), 'al-Hijab' (The Veil), 'al-Hawiyah' (The Abyss) and 'al-Iqab' (The Punishment) are described as mawdu'ah (composed i.e. original), while the remaining four 'al-shuhada' (The Martyrs), 'al-Dhikra' (The Remembrance), 'al-Jaza' (The Reward) and 'al-Dahiyya' (The Victim) are described as mutarjamah (translated). One original story ' $a$ l-Iqab' is described in a footnote as having been composed in the manner of an American story, a description that rises more questions than it answers; at the very least, however, it presumably indicates an acquaintance, on the part either of al-Manfaluti himself or of one of his collaborators, with one or more collections of American short stories, either in Arabic translation or in the case of a collaborator in the English original. ${ }^{[9]}$

Of the translated stories two derive from works by the French writer and diplomat Chateaubriand. Of these 'al-Shuhada' is based on the French original Atala (1801), a story in which the theme of the 'noble savage', so beloved of the French Romanticists, plays a prominent part. While the second, 'al-Dhikra', is based on an original entitled Les aventures du dernier Abencerage (1826), this story with its historical setting during the period of the collapse of Islamic rule in Spain, seems to sit slightly uneasily in the collection as a whole. A third story 'al-Dahiyyah' the last and longest in the collection is derived from Alexandre Dumas Fils's La dame aux camellias (1848), a story that was subsequently to reappear as the libretto for Verdi's La Traviata, and that has been aptly described both as a four handkerchief tale and as exemplifying G.K.Chesterton's category of 'good bad books'. ${ }^{[0]}$

Insofar as the collection possesses a unity, what links these stories together is a pervasive sentimentality and pessimism that makes the volume title 'al-Abarat' a particularly apt one. The mood is set with the work's 'Dedication', in which the author speaks of shedding his tears before the wretched of the world, "in the hope that they will find some comfort and solace in my weeping over them". Scarcely a page of collection lacks some form of sadness or unhappiness. A particularly common pattern in the narrative is the descent of an individual, or individuals, into illness, death or some other form of misery, evoking the narrator's and by implication, also the reader's, reflections and compassion. Thus, all of the first four stories in the collection end in graveyards.

A link to some of the themes of 'al-Nazarat' is provided by "al-Hijab", which relates the progressive disintegration of a man who has spent several years in Europe to return a changed man; here al-Manfaluti casts his story in the form of a moral tale intended to represents a warning to the reader about the lax morals of the West and the dangers of their intruding into Egypt. Reflections on a period of residence in the west, either in fictional or non-fictional form, had not unnaturally provided one of the standard to poi for Arab writers during the nineteenth century and they have continued to provide productive subject-matter until this day; for $a l$ Manfaluti, however, who had not only not visited Europe but had almost certainly never left his native Egypt. The theme- far from providing the opportunity to expand intellectual horizons that it had for other writersseems to be merely another excuse to rehearse the anti-Western and anti-feminist sentiments. ${ }^{[1]]}$

Despite its popularity with some groups of readers, it is hardly surprising that al-Abarat has generally found a cool reception from the critics. Although the narrative generally flows easily, the stories almost entirely lack the wit and sparkle of the best pieces of al-Nazarat and the range of subject matter and emotional experience to which al-Manfaluti apparently has access are so limited that the collection almost seems to reveal the limitations of the author rather than his capabilities. Most readers will probably find it hard to put the book down without the feeling that "enough is enough".

\section{Conclusion:}

Al-Manfaluti had a far greater influence on the literature of his day than writers on the subject have given him credit for. His work, however, must not be judged in the light of permanent artistic achievement, for he did not excel in any of the literary genres which he attempted. His translations, as such, fail drastically, being but a free interpretation of the theme and mood of the translated work. The original stories which he wrote cannot stand the test of good story writing. They are merely a pale imitation of the stories he translated. His articles on social and moral issues are now out-dated and can only appear to the modern reader as the somewhat naive writings of an old fashioned Azhari with a limited culture. Yet he is one of the few early twentieth century writers who won great popularity in their lifetime, and whose works are still very much alive in the Arab world. Writers on the subject seem to think that his popularity was due to his fluent, easy, lucid, vivacious and highly emotional style. Yet style alone cannot be the only reason why al-Manfaluti was able to win such immediate popularity and to keep it with the successive generations.

Al-Manfaluti's great talent showed itself first of all in his instinctive realization of what was needed in literature at that time, namely, reading material of a kind that could satisfy the emotional promptings of a society newly awakened to its own handicaps and disappointments, which would forge a link with the west and at the same time, keep a grasp of the best in the old traditions both in style and ideas. This came easily to him because 
he did not know any Western language. He had therefore to limit his fascination with Western literature to a form of indirect translation through intermediaries, which enabled him to keep to a purely Arabic style.

\section{References:}

[1]. Brugman, J., An Introduction to the History of Modern Arabic Literature in Egypt, Leiden, 1984, P-83.

[2] Daif, Shawqi 1974. Al-Adab al-Arabi al-Muathir fi Misr. $5^{\text {th }}$ ed. Cairo: Dar al-Ma'arif bi Misr, P-227.

[3]. Brugman, J., An Introduction to the History of Modern Arabic Literature in Egypt, Leiden, 1984, P-83.

[4]. Ibid, P-84.

[5]. Moosa, Matti, The Origins of Modern Arabic Fiction, PP-109-110.

[6]. Badawi M.M., Modern Arabic Literature, Cambridge, 1992, P-275.

[7]. Mahdi, Ismat, Modern Arabic Literature, Hyderabad (India), 1983, PP-29-30.

[8]. Moosa, Matti, The Origins of Modern Arabic Fiction, P-111.

[9]. Al-Anwar, Dr. Muhammad Abu, Al-Manfaluti: Imam al-Bayan al-Arabi, $1^{\text {st }}$ ed. Cairo: al-Dar al-Misriyya al-Lubnaniyya, 2000, P62.

[10]. Moosa, Matti, The Origins of Modern Arabic Fiction, P-111.

[11]. Starkey, Paul, Modern Arabic Literature, Edinburgh University, 2006, P-109. 